Geologic Interpretation of

Gravity and Aeromagnetic

Maps of Tintic Valley and

Adjacent Areas, Tooele and

Juab Counties, Utah

GEOLOGIGAL SURVEY PROFESSIONAL PAPER 516-D 



\section{Geologic Interpretation of}

Gravity and Aeromagnetic Maps of Tintic Valley and Adjacent Areas, Tooele and Juab Counties, Utah By D. R. MABEY and H. T. MORRIS GEOPHYSICAL FIELD INVESTIGATIONS

GEOLOGICAL SURVEY PROFESIONAL PAPER 516-D Geophysical data indicate the thickness of Cenozoic sedimentary and volcanic rocks and the distribution of igneous rocks

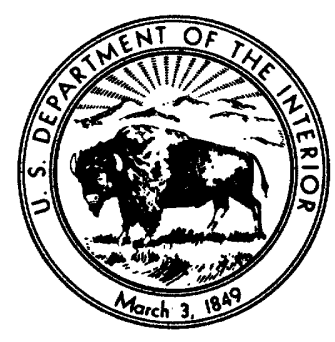




\section{UNITED STATES DEPARTMENT OF THE INTERIOR \\ STEWART L. UDALL, Secretary \\ GEOLOGICAL SURVEY \\ William T. Pecora, Director}




\section{CONTENTS}

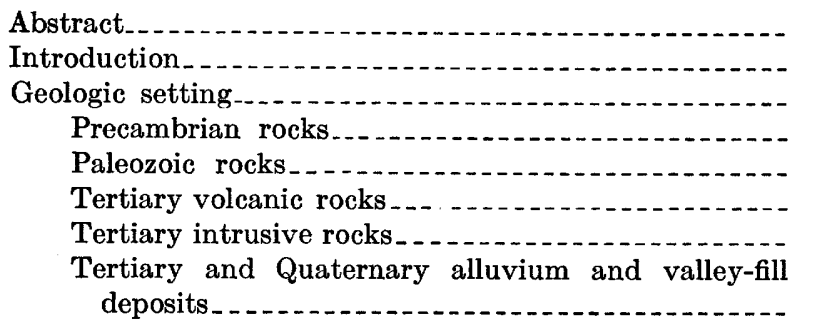
Page | Geologic setting-Continued Page
D1 Structure of the Tintic Valley area__._._. D4

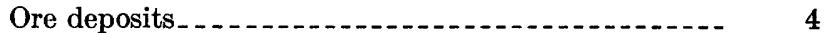
Gravity and magnetic surveys
Gravity and magnetic maps...... 5
East Tintic Mountains anomalies....... 5
Tintic Valley anomalies _... 6
West Tintic and Sheeprock Mountains anomalies_- 8
Interpretation of regional structure. $\quad 9$
4 References cited..... 9

\section{ILLUSTRATIONS}

Plate 1. Geologic maps and section showing gravity and magnetic data, Tintic Valley and adjacent areas, Tooele and Juab Counties, Utah........ In pocket

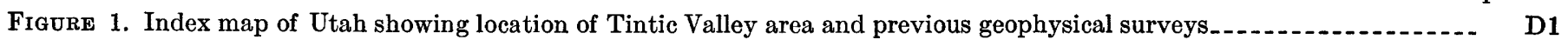

\section{TABLE}





\title{
GEOLOGIC INTERPRETATION OF GRAVITY AND AEROMAGNETIC MAPS OF TINTIG VALLEY AND ADJAGENT AREAS, TOOELE AND JUAB COUNTIES, UTAH
}

\author{
By D. R. Mabey and H. T. Morris
}

\begin{abstract}
A 30-milligal gravity low in Tintic Valley indicates that about 7,000 feet of low-density sedimentary and volcanic rocks of Cenozoic age is present in the valley and that these rocks are thickest east of the center of the valley. Normal faults with large vertical throw are inferred along the east side of the valley, and normal faults with smaller throw are inferred on the west side. Small gravity lows, also reflecting Cenozoic rocks, occur northwest of Rockwell Ranch and along Vernon Creek.

A west-trending zone of magnetic anomalies across Tintic Valley indicates a belt of abundant igneous rock, which also ex. tends west of the valley to the Wasatch Range. Over the East Tintic Mountains an 800-gamma magnetic high has two major closures. One is over intrusive igneous rocks exposed near Silver City; the other is over volcanic rocks west of Tintic Mountain. Both magnetic features are believed to reflect a large intrusive body underlying the southern half of the East Tintic Mountains. Smaller magnetic highs are produced by intrusive rocks in the Sheeprock and West Tintic Ranges and at Desert Mountain. A zone of high magnetic intensity extending across Tintic Valley at McIntyre Siding indicates that volcanic rocks underlie the southern part of the valley. Elsewhere volcanic rocks are reflected by both positive and negative magnetic anomalies.

The geophysical data do not support the concept of a basement uplift in the Sheeprock Mountain area, but they are consistent with a structural interpretation that assigns the Precambrian sedimentary rock in this area to the upper plate of a major overthrust.
\end{abstract}

\section{INTRODUCTION}

Aeromagnetic and gravity maps of the area adjacent to Tintic Valley, Utah, were prepared as part of a continuing geophysical study of the Basin and Range province (fig. 1). These maps, which cover an area of about 600 square miles including parts of the East Tintic, West Tintic, Sheeprock, and Simpson Mountains, are overprinted on a generalized geologic map compiled from original and published (chiefly Stokes, 1963) sources. The east boundary of the map overlaps the west edge of a gravity map of the central and southern Wasatch front by Cook and Berg (1961) and an aeromagnetic map of approximately the same area by Mabey, Crittenden, Morris, Roberts, and Tooker (1964).

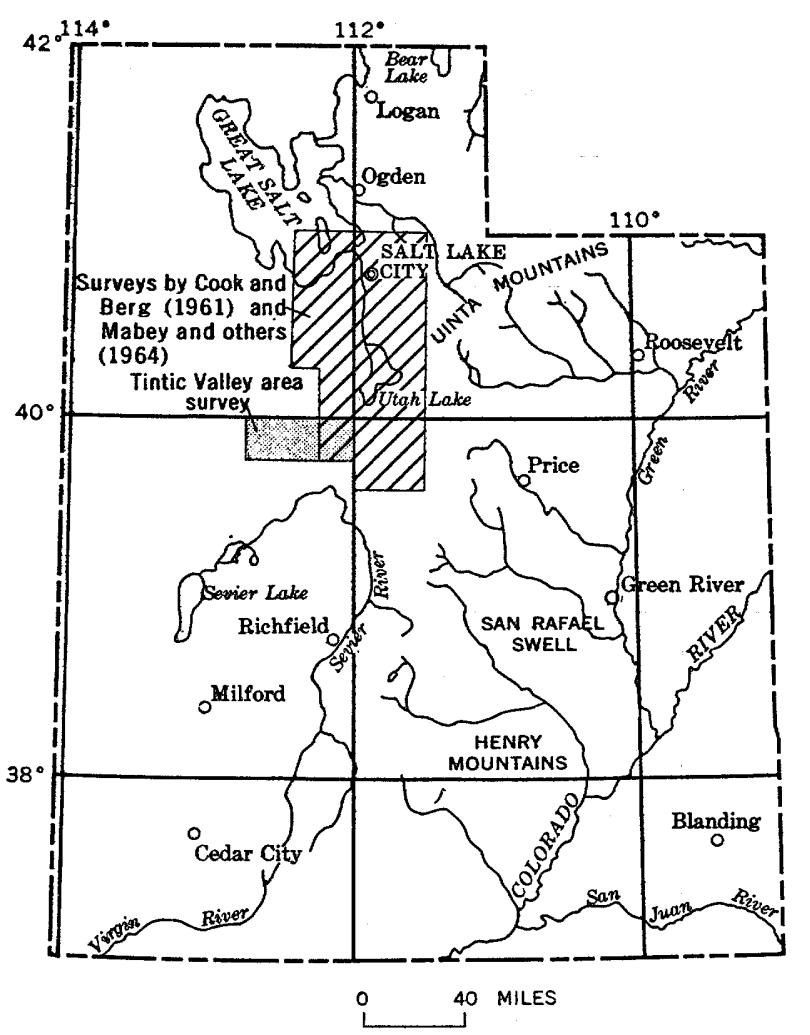

FIGURE 1.-Location of Tintic Valley area and areas covered by previous geophysical surveys.

\section{GEOLOGIC SETTING}

Tintic Valley is a fault-rimmed intermontane basin in the east-central part of the Basin and Range province (pl. 1). It is bordered on the east by the southern half of the East Tintic Mountains, a tilted fault-block range, and on the west by the West Tintic and Sheeprock Mountains, which form part of a complex horst. The valley and adjacent ranges include the eastern part of a belt of intrusive rocks and mining districts that extends from the East Tintic Mountains to the Deep Creek Range; other concealed stocks and mineralized areas may underlie lavas and Quaternary deposits within this belt. 
The rocks exposed in the mountains adjacent to Tintic Valley range in age from Precambrian to Recent and include rocks deposited during each period of the Paleozic Era. No rocks of Mesozoic age crop out, but regional geologic relations suggest that Triassic and Jurassic rocks may deeply underlie some of the Precambrian and Paleozoic rocks below thrust faults of large displacement, at least in the southeastern part of the East Tintic Mountains. The Tertiary and Quaternary rocks in the area are of volcanic and continental origin and vary widely in composition and thickness.

The stratigraphic sections are summarized in table 1.

\section{PRECAMBRIAN ROCKS}

The oldest rocks exposed near Tintic Valley consist of a thick sequence of clastic sedimentary rocks interlayered with a few thin diabase sills or basalt flows. Cohenour (1959, p. 17-18) described two major se-

TABLE 1.-Stratigraphic sections of rocks exposed in the Simpson, Sheeprock, West Tintic, and East Tintic Mountains [Figures in parentheses indicate thickness, in feet]

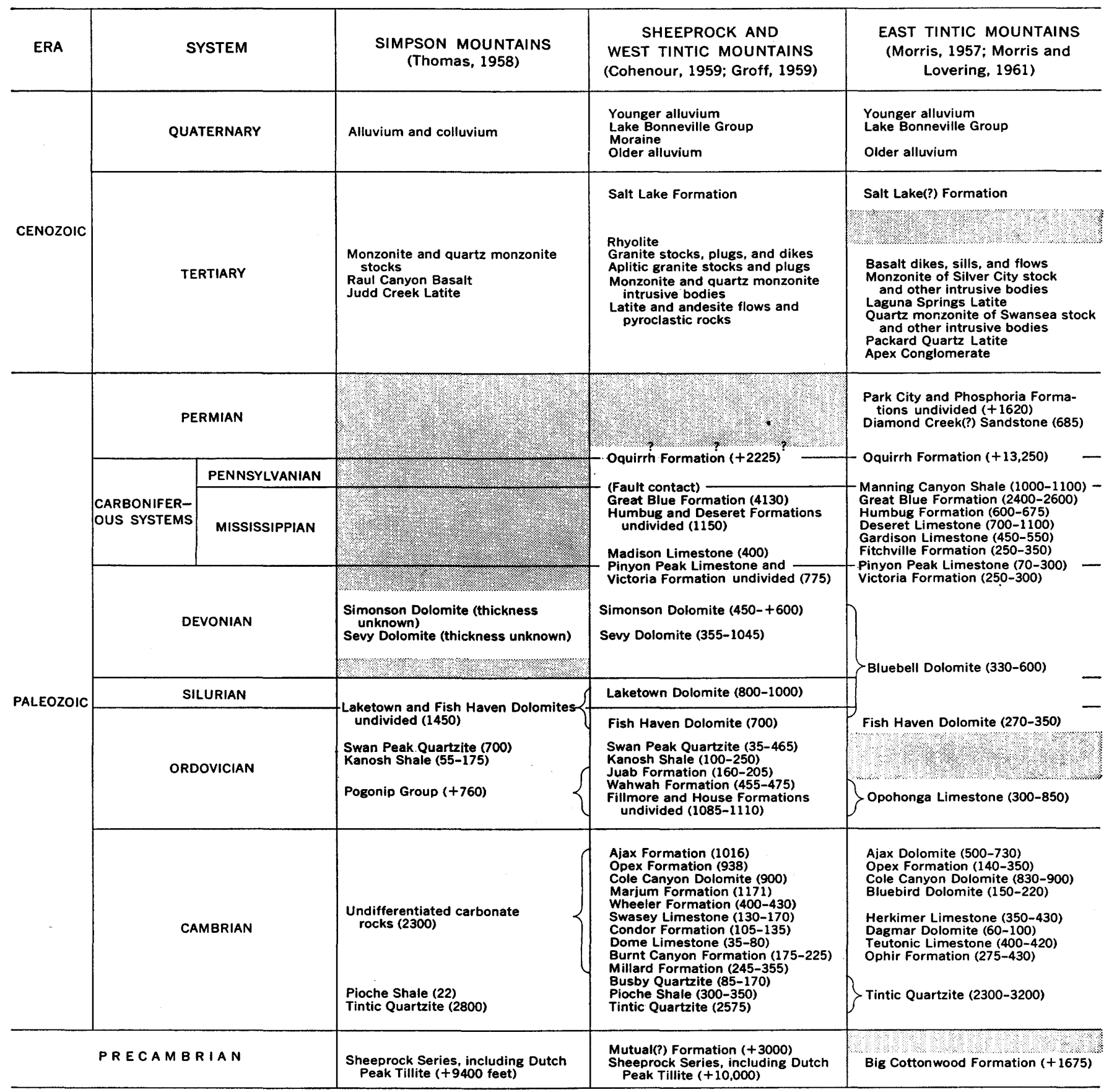


quences of these rocks in the Sheeprock Mountains. The older sequence, termed the Sheeprock Series, is 9,00010,000 feet thick and consists of a lower sequence of slaty phyllite and quartzite, a middle sequence of schistose tillite, and an upper sequence of quartzite and phyllite. The younger sequence, provisionally correlated with the Mutual Formation of the Wasatch Mountains, is about 925 feet thick and consists of a lower argillite member and an upper member of conglomeratic quartzite. In the East Tintic Mountains the Precambrian rocks resemble the lower part of the Sheeprock Series and have been correlated with the Big Cottonwood Formation (Morris and Lovering, 1961, p. 10-13) of late Precambrian age. Quartzite, slate, and argillite, identified as the Sheeprock Series by Thomas (1958, p. 4-7), make up large parts of the Simpson Mountains. No tillite was recognized by Thomas in the exposures of Precambrian rock in the Simpson Mountains; therefore, the stratigraphic position of the tillite in this area is unknown.

The base of the upper Precambrian rocks is not exposed in the area adjacent to Tintic Valley. Presumably these stratified rocks overlie gneiss and schist comparable to the Farmington Canyon Complex (Eardley and Hatch, 1940, p. 61) or the Little Willow Formation (Crittenden and others, 1952, p. 3), which are both exposed in the Wasatch Range.

\section{PALEOZOIC ROCKS}

Carbonate and clastic rocks of Paleozoic age crop out extensively throughout the area studied. In the East Tintic Mountains the aggregate thickness of Paleozoic rocks is close to 30,000 feet. Groff (1959) reported at least 11,500 feet of carbonate and clastic rocks of Cambrian through Pennsylvanian age in the West Tintic Mountains, and Cohenour (1959, p. 12) described more than 19,500 feet of Paleozoic rocks in the Sheeprock Mountains. Although the sections of Paleozoic rocks exposed in these mountain ranges are generally alike, correlation of specific formational units across the major valleys is complicated by the juxtaposition of dissimilar sedimentary rock facies by exposed and concealed thrust faults.

\section{TERTIARY VOLCANIC ROCKS}

Lavas and pyroclastic rocks, ranging in composition from rhyolite and quartz latite to basalt, blanket the Precambrian and Paleozoic rocks chiefly on the east sides of the westward-tilted ranges. The extensive lavas in the East Tintic Mountains have been dated as middle to late Eocene on the basis of regional stratigraphic relations, physiographic considerations, and by isotope methods (Morris, 1957, p. 29-34). Parts of the less extensive lava and pyroclastic deposits in the West Tintic, Sheeprock, and Simpson Mountains are probably comparable in age, although no specific correlations are possible from the data at hand.

\section{TERTIARY INTRUSIVE ROCKS}

Stocks, plugs, dikes, and other intrusive bodies ranging in composition from granite to diabase cut all the pre-Miocene rocks exposed near Tintic Valley. The oldest intrusions that have been dated are middle to late Eocene (Morris, 1957, p. 29-39), and the youngest may be Miocene (Cohenour, 1959, p. 100). These intrusive bodies form part of a belt of intrusions 20-30 miles wide extending from the central Deep Creek Range at the Nevada border eastward to the East Tintic Mountains and possibly beyond to the southern Wasatch Range (Mabey and others, 1964).

The intrusions exposed in the East Tintic Mountains are chiefly porphyritic monzonite and quartz monzonite, but they also include some diabase dikes and sills. The largest intrusion in this range is the Silver City monzonite stock, which crops out over an irregular area of about 2 by 3 miles.

Some of the intrusions in the southern part of the West Tintic and Sheeprock Mountains are also porphyritic monzonites and quartz monzonites, but others include a wide dike of rhyolitic vitrophyre ${ }^{1}$ and plugs of aplitic granite in the southern Sheeprock Mountains, and several pluglike intrusive bodies of uncertain composition in the southern West Tintic Mountains.

The large intrusive body cut by Cottonwood and Rock Canyons in the western part of the Sheeprock Mountains is a leucocratic granite containing scattered pegmatitic segregations of beryl and other uncommon minerals (Williams, 1954; Cohenour, 1959, p. 100-101). It is similar to a coarse-grained leucocratic granite exposed in Desert Mountain.

The small intrusive bodies in the Simpson Mountains consist chiefly of plugs and dikes of latite and monzonite. The largest plug crops out over an area of only 800 by 1,400 feet (Thomas, 1958, p. 15).

\footnotetext{
1 After this paper had been prepared for publication, several large diatremes composed of rhyolite and rhyolitic vitrophyre and containing giant blocks of Precambrian and Paleozoic sedimentary rock were discovered in the upper part of Cherry Creek near the center of the mapped area. The presence of these intrusive bodies, then, makes inaccurate the geology as shown on plate 1 , particularly the distribution of Precambrian sedimentary rocks and the position of the southeastern edge of the Sheeprock overthrust. Although the igneous matrix material of the diatremes is highly leucocratic and its contained magnetite is commonly pyritized, these volcanic rocks may account for the magnetic anomalies on either side of the central and upper parts of Cherry Creek. (See p. D8.)
} 


\section{TERTIARY AND QUATERNARY ALLUVIUM AND VALLEY-FILI DEPOSITS}

The intermontane basins, particularly Tintic Valley, are filled with an irregular thickness of fanglomerate, volcanic debris, lacustrine sediments, and alluvium. The oldest of these deposits are part of the Salt Lake (?) Formation of Pliocene age. They consist most typically of conspicuously bedded bentonitic clays and tuffaceous marly limestone interlayered with lenses of sand and gravel and wedge-shaped masses of coarse fanglomerate. Pleistocene and Recent deposits overlie faulted and tilted beds of the Salt Lake (?) Formation, and consist of fanglomerate, loess, and alluvium. Sediments deposited in ancient Lake Bonneville during Wisconsin time mantle all but the youngest alluvium below an elevation of about 5,150 feet.

\section{STRUCTURE OF THE TINTIC VALLEY AREA}

The major structural features of the Tintic Valley area are thrust faults, folds, and transcurrent faults that are older than the Eocene lavas, and Basin-andRange normal faults that cut even the most recent deposits and form the boundaries of the major topographic features. The structures that formed before the lava was extruded originated in response to tectonic uplift during late Mesozoic time, which resulted in the detachment of several great sheets of stratified rocks that glided east toward a Cretaceous sedimentary basin that Spieker (1949, p. 20) and Schoff $(1951$, p. 643644 ) recognized about 35 miles east of the Tintic Valley area. The folds, thrusts, and transcurrent faults of the East Tintic Mountains formed during compressional deformation of one of these thrust sheets. Other sheets also show minor folding, thrusting, and tear faulting. The youngest features that predate extrusion of the lava are east-trending normal faults of large throw.

The Basin-and-Range faults are arcuate in plan, but in general they trend northward or northeastward. The most prominent of these faults defines the west edge of the East Tintic Mountains, where local scarps in Pleistocene and younger fanglomerates attest to recent vertical displacement. Many of the late normal faults elsewhere in the Tintic Valley area are not easily recognized where they cut poorly consolidated alluvium and fanglomerate, and they are known chiefly from geophysical surveys.

\section{ORE DEPOSITS}

Several mining districts that have produced large quantities of base-metal and silver ores are located in the East Tintic, Sheeprock, and Simpson Mountains. The most productive districts are close to monzonite and quartz monzonite stocks that cut carbonate rocks of
Paleozoic age. North of the stocks in the central East Tintic Mountains are the rich Tintic and East Tintic districts, which have produced ores of silver, lead, zinc, copper, and gold valued at about $\$ 450$ million, and which still contain large reserves of silver, lead, and zinc. The smaller metalliferous districts in the Sheeprock and Simpson Mountains have been far less productive, but they contain much unexplored ground. Of particular interest to the geophysicist and exploration geologist are the large areas covered by postmineralization valley-fill deposits and alluvium near the major ore-producing centers. Presumably these areas may contain extensions of the major districts or undiscovered districts of comparable richness.

\section{GRAVITY AND MAGNETIC SURVEYS}

A regional gravity survey along the central and southern Wasatch front by Cook and Berg (1961) included 40 stations in Tintic Valley and the East Tintic Mountains. To better define the gravity anomalies in Tintic Valley and the East Tintic Mountains, and to extend the coverage over the West Tintic Mountains and the southern part of the Sheeprock Range, 232 new gravity stations were established in 1963. The new data from these stations were tied to those of the base network of the original survey, and 12 of the original stations were reoccupied to test the accuracy of the tie.

The gravity datum for the survey by Cook and Berg was referenced to the U.S. Coast and Geodetic Survey pendulum station at Salt Lake City (Duerksen, 1949). A subsequent tie of one of the base stations used by Cook and Berg to the gravity control network in North America (Behrendt and Woollard, 1961) indicated that the datum they used was 2.2 mgals (milligals) below the North American network. The datum used in this report is based on a value of 979800.1 mgals determined by Behrendt and Woollard for the Liberty Park (Salt Lake City) base station.

The gravity data were reduced to the complete Bouguer anomaly using an elevation correction factor corresponding to a density of $2.67 \mathrm{~g} \mathrm{per} \mathrm{cm}^{3}$ (grams per cubic centimeter) for the rocks above sea level. Terrain corrections were computed on an electronic digital computer (Kane, 1962). The corrections were made for terrain in a $40-\mathrm{km}$ square with the station at the center. Latitude and curvature corrections were computed using the methods described by Swick (1942).

Total magnetic intensity was measured with an AN/ ASQ-3A magnetometer. East-west flight lines generally 1 mile apart were flown at a barometric elevation of 9,000 feet above sea level. The data were compiled on U.S. Geological Survey topographic quadrangle maps and were reduced to a scale of $1: 125,000$ (pl. 1). 


\section{GRAVITY AND MAGNETIC MAPS}

The dominant feature on the gravity anomaly map is a 30-mgal low in Tintic Valley. This low, two smaller lows near Cherry Creek, and the low east of the East Tintic Mountains probably are produced primarily by the density contrast between sedimentary and volcanic rocks of Cenozoic age and the more dense older rocks. In the mountains the anomaly values have a range of about 15 mgals.

The aeromagnetic map of part of north-central Utah (Mabey and others, 1964) reveals a zone of magnetic anomalies south of the 40th parallel of latitude that is approximately coextensive with an area of Tertiary volcanic rock. The area of magnetic map presented here lies along the north edge of this zone. A high over the East Tintic Mountains is the largest magnetic anomaly in the area. At the 9,000-foot flight level, the anomaly consists of two closed magnetic highs. The smaller of the two closures is over an exposed intrusive stock, and the larger closure is over volcanic rocks on the west side of the East Tintic Mountains. In other areas smaller local anomalies are associated with both volcanic and intrusive rock. Relatively gentle magnetic gradients and low-amplitude anomalies occur over exposed sedimentary rocks of Precambrian and Paleozoic age.

\section{EAST TINTIC MOUNTAINS ANOMALIES}

Moderate gravity anomalies and large magnetic anomalies occur in the East Tintic Mountains. The Bouguer gravity values range from a high of -178 mgals on Paleozoic rock near the north edge of the map to a low of -190 mgals on Tertiary igneous rocks between Silver Pass and Buckhorn Mountain. Over the Tertiary igneous rocks in the central and southern parts of the range, the magnetic map is dominated by an extensive area of high intensity with the maximum values about 800 gammas above the general level. North of this extensive high there are magnetic highs and lows over the Tertiary volcanic rock.

In the East Tintic Mountains near the north edge of the mapped area, relatively low gravity values and a magnetic high occur over volcanic rocks west of the Eureka Lilly-Selma fault zone. Part of the magnetic high doubtless reflects the effect of terrain, as the highest magnetic intensity was measured where the terrain clearance was smallest; however, the main part of the anomaly is not related to terrain. The gravity and magnetic anomaly west of the Eureka Lilly-Selma fault zone could be produced by the thick lobe of volcanic rocks, but the absence of a comparable magnetic high over similar thick volcanic rocks a few miles to the east and the generally gentle gradients associated with the anomaly suggest that the magnetic anomaly is not produced by lavas and pyroclastic deposits, but that it reflects a concealed intrusive mass. Indirect evidence for an intrusive mass may possibly be found in the interpretation that the deep, north-plunging base-metal and silver ore bodies of the northern part of the Tintic mining district were deposited in part from solutions rising from a concealed source, possibly an unexposed igneous intrusion, in this area.

The magnetic intensity over the volcanic rocks northeast and east of Silver Pass is generally low, but local variations of over 200 gammas were defined at the 9,000foot elevation. An earlier survey of part of this area (unpub. data) with flight lines 1,000 feet above the surface revealed local negative anomalies of over 300 gammas associated with inversely magnetized latite flows. The net magnetic effect of these volcanic rocks appears to be negative, indicating that much of this rock has an inverse remanent magnetization.

The gravity values northeast of Silver Pass do not appear to be strongly influenced by local variation in thickness of the volcanic rock, although the volcanic rocks, which cover an irregular terrain, are absent in some places and and are more than 2,800 feet thick in others.

A magnetic high centered over the monzonite stock at Silver City extends over several of the larger exposures of intrusive rock in this area, including the older Swansea Quartz Monzonite. Alteration has destroyed much of the magnetite in the Swansea Quartz Monzonite, and the susceptibility is much lower than that of the Silver City monzonite stock. However, the Swansea and Silver City stocks and other related intrusive bodies are reflected on the map as one anomaly. The position of the magnetic maximum suggests that the intrusive rock is more abundant or has greater depth extent along the west side of the range. The magnetic data suggest that the intrusive rocks in the Silver Pass area are sills and dikes, which converge with the Swansea-Silver City stocks at depth.

Monzonite porphyry crops out at Diamond Gulch in a magnetic saddle. The relatively low magnetic intensity over this outcrop suggests that it has limited depth extent or low susceptibility. Geologic field relations suggest that the outcrops are part of a sill-like mass.

An extensive magnetic high is centered over the west side of the range west of Tintic Mountain. Along the north edge of this high, a stock of monzonite porphyry is exposed, and smaller bodies of similar rocks are exposed to the south and east. Tertiary volcanic rocks cover most of the area of the anomaly.

Susceptibilities were determined for 17 samples of intrusive and extrusive igneous rocks in the East Tintic 
Mountains. Susceptibilities of 11 samples of volcanic rocks range from 0.27 to $5.41 \times 10^{-3} \mathrm{cgs}$ (centimetergram-second) units and average $2.90 \times 10^{-3} \mathrm{cgs}$ units. Three samples of the Silver City monzonite have susceptibilities of $2.74,3.48$, and $5.40 \times 10^{-3} \mathrm{cgs}$ units; one of monzonite porphyry from Sunrise Peak stock is $2.07 \times 10^{-3} \mathrm{cgs}$ units; two of the hydrothermally altered Swansea Quartz Monzonite are both $0.02 \times 10^{-3} \mathrm{cgs}$ units. These susceptibilities indicate that either the unaltered monzonite or the volcanic rocks could produce the magnetic high over the East Tintic Mountains if a sufficient thickness-in excess of 10,000 feet-of either were present. Several lines of evidence suggest that the greater part of the anomaly is produced by an underlying magnetic mass, presumably an igneous intrusive body. Paleozoic sedimentary rocks are exposed in a window near the area of the highest magnetic intensity, and it seems reasonable to infer that the volcanic rocks over the area adjoining this window are relatively thin. The highest intensity does not occur where the terrain clearance is lowest, which suggests that the surface rocks are not the primary cause of the anomaly. Over Tintic Mountain, which is the highest point in the range, the magnetic intensity is decreased, which suggests that volcanic rock there is inversely magnetized and thus is not contributing to the large positive anomaly. A strong local high of about 500 gammas occurs over exposed monzonite in the Silver City area, showing that the monzonite does produce anomalies of this amplitude. No clear evidence indicates that similar anomalies are produced by the volcanic rock.

We conclude that a large mass of intrusive rock with magnetic properties similar to monzonite underlies the East Tintic Mountains from Mammoth south to the head of Furner Creek. Local features within the composite magnetic high may reflect either variations in the thickness or magnetization of the volcanic rock, the geometry of the underlying magnetic mass, or compositional variations within the mass. The magnetic high is partly bounded by linear zones of steep magnetic gradient. The most prominent of these zones trend northeast and northwest. Numerous major faults within the Paleozoic rocks in the region trend northeast, and some of them have substantial components of both rightlateral and left-lateral displacement. Northwest-trending faults are not so prominent in the Paleozoic rocks; however, a zone of northwest-trending normal and strike-slip faults north of Boulter is on a projection of the trend of the steepened magnetic gradient bounding the magnetic high on its northeast margin. The linear zones bounding the magnetic anomaly and their relation to trends of known faults suggest fault control for the margins of the intrusive mass believed to be producing the anomaly.

The gravity values in the area of high magnetic intensity in the East Tintic Mountains are the lowest observed in the ranges in the area of this survey. Although thick accumulations of pyroclastic rocks may be part of the cause of the low gravity values, the lowest values are over the Tertiary intrusive rock and probably reflect a density contrast between intrusive rock and the generally more dense pre-Tertiary rock.

The gravity values on Paleozoic rock in the Pinyon Peak area at the north end of the mapped area are higher than the values on Paleozoic rock near the south end of the range, and a part of the southward decrease in gravity values between Pinyon Peak and Silver Pass is probably a broad regional gravity variation.

\section{TINTIC VALIEY ANOMALIES}

On the west side of the East Tintic Mountains the gravity values decrease abruptly into the large gravity low in Tintic Valley. The gravity anomaly is asymmetric, with the lowest values and the steepest gradients on the east side. A continuous zone of steep gravity gradients forms the east margin of the low from the north edge of the map to Riley Canyon. South of Riley Canyon the gradient is gentler. Along the west side of the valley several zones of relatively steep gravity gradients are apparent, but more detailed observations are needed to adequately define the gravity variations in this area. The amplitude of the gravity anomaly decreases where the valley is constricted at the north and south ends.

The gravity low undoubtedly is produced primarily by low-density sedimentary and volcanic rocks of Cenozoic age. No deep holes have been drilled in the valley, and we have no direct control on the thickness or density of the material underlying the valley. Material about 7,200 feet thick with a density $0.45 \mathrm{~g}$ per $\mathrm{cm}^{3}$ lower than the enclosing rock would produce the measured gravity anomaly. The $0.45 \mathrm{~g}$ per $\mathrm{cm}^{3}$ density contrast assumes densities of 2.7 and $2.25 \mathrm{~g}$ per $\mathrm{cm}^{3}$ for the Paleozoic and Cenozoic rocks respectively. This density contrast has proved applicable in other parts of the Basin and Range province.

Over Tintic Valley the magnetic anomalies are smaller than over the East Tintic Mountains, but significant variations in the magnetic field do occur. A zone of high magnetic intensity extends across the south end of the valley. This zone is continuous with the large high over the southern part of the East Tintic Mountains and another area of high intensity over the southern part of the West Tintic Mountains. The fact that the large magnetic high over the East Tintic Moun- 
tains extends over the east edge of the valley suggests that the magnetic mass producing the anomaly is not terminated at the range front. From this high zone in the valley the magnetic intensity generally decreases northward with minor irregularities. A 100-gamma high, largely within the valley, is present west of Boulter.

The magnetic data provide indication of the nature of the material underlying the valley. The zone of high intensity across the southern part of the valley reveals that igneous rocks are present in the subsurface. The low gravity values over part of the zone suggest that the rocks involved, at least in part, have low density; presumably they are similar to the extrusive rocks that are exposed in this magnetic zone 4 miles west of McIntyre Siding. The northward decrease in magnetic intensity in the valley probably reflects a decrease in the amount of magnetic material in the valley fill or an increasing depth to the top of a magnetic basement underlying the sedimentary rocks. The local high west of Boulter indicates that the volcanic rock exposed under the south end of the anomaly extends into the valley under the Quaternary cover. The amplitude of this anomaly compared with that of areas of exposed volcanic rock suggests an anomalous concentration of magnetic material; perhaps it is an eruptive center.

An analysis of the gravity gradient along the east side of the valley indicates that a single high-angle fault separating two density units could not produce the observed anomaly. Three possible configurations could produce the anomaly: (1) two or more highangle step faults, (2) a low-angle interface, and (3) a major high-angle fault combined with decreased density of the Quaternary and Tertiary sedimentary rocks toward the center of the valley.

In making the two-dimensional analysis of the gravity data along profile $A-A^{\prime}$ (pl. 1), we attributed the gravity low in Tintic Valley to a combination of Quaternary and Tertiary sedimentary rocks and Tertiary volcanic rock with density contrasts of 0.45 and $0.22 \mathrm{~g}$ per $\mathrm{cm}^{3}$ respectively, relative to the pre-Tertiary rocks. If the density of the sedimentary rocks decreases toward the center of the valley, some of the inferred faults may be steeper and the displacement of the range-front fault greater. We have assumed that the depression of the valley has occurred along normal faults that dip $45^{\circ}$. The gravity data require that the fill thicken immediately west of the front of the East Tintic Mountains where we infer the presence of a range-front fault. The existence of a fault within the valley is indicated by the steepening of the gravity gradient near Tintic Junction. South of the profile the magnetic anomaly associated with the Swansea and Silver City stocks ex- tends into the valley without any indication that the top of the stock is displaced by a large amount at the range front. However, the west boundary of the area of highest intensity is approximately coincident with the western inferred fault. Along the profile, Tertiary volcanic rocks are exposed on the west side of the valley and low-amplitude magnetic highs suggest that volcanic rock underlies the sedimentary rocks in the valley. An irregular layer of volcanic rock, as much as 1,000 feet thick, has been assumed to underlie most of the valley; however, the thickness of the volcanic rock may differ substantially from the assumed thickness.

The pattern of the faulting indicated by the gravity data is continuous along the east side of the valley north of Riley Canyon. The bend in the major zone of gravity relief west of Mammoth could be produced by an are in the fault zone or by the intersection of two linear zones. The gravity data indicate that the displacement along the inferred fault zone continues to the north edge of the mapped area, but that toward the south the displacement diminishes along both faults.

The structure of the west side of Tintic Valley is complex and the gravity data are sparse. Along profile $A-A^{\prime}$ two faults are inferred on the basis of two zones of steepened gravity gradients. Elsewhere the gravity data are not sufficiently detailed to define the structure; however, it is clear that faults along the west side of the valley produce strong vertical displacement. The dominant trend of the individual faults is probably slightly west of north.

Three local gravity highs, which show as noses on the contour map, are superimposed on the general westward gravity rise on the west side of the valley. The northernmost correlates with the northern part of the magnetic high west of Boulter and indicates that the magnetic body is also a positive mass anomaly relative to enclosing valley fill. The anomaly is approximately alined with a ridge of volcanic rock to the south, and it may reflect a subsurface extension of this ridge. The gravity nose immediately west of Boulter does not correlate with any structure apparent at the surface, but it probably also reflects a buried ridge. The third nose is coincident with an outcrop of volcanic rock in the valley south of Devil Creek and indicates that this outcrop is part of a north-trending partly buried ridge.

The south end of the valley is constricted by a largely buried hill of pre-Tertiary rock extending into the valley from the west. The gravity data suggest that this buried hill is bounded on the north and east by faults.

The gravity and magnetic data suggest two major Cenozoic structures in Tintic Valley. The first is related to the magnetic zone across the southern part of 
the valley. This zone is coincident with an alinement of minor intrusive bodies extending westward from Tintic Mountain through the southern part of the West Tintic and Sheeprock Mountains, and it is also coincident with Eocene volcanic rock present in the ranges and exposed in one area in the valley. The relatively high magnetic intensity in this zone probably reflects both volcanic rock underlying the valley and a deepseated source for the minor intrusive bodies. Within the valley, Bouguer gravity values over the magnetic zone are 20 mgals lower than over Paleozoic rock to the south and west, and steep gravity gradients suggesting faults form the south and west boundary of the low. Eocene hypabyssal and volcanic rocks, perhaps interlayered with and locally overlain by sedimentary rocks, are probably the primary source of the gravity anomaly. The volcanic rock may have accumulated in an easttrending trough, or it may have been preserved in a depression that formed after the Eocene volcanism. The second structure is the north-trending asymmetric graben formed during the episode of Basin-and-Range faulting, which began in latest Oligocene or earliest Miocene time. This graben, which crosses the inferred trough of Eocene volcanic rock, was filled with both sedimentary and pyroclastic rocks.

\section{WEST TINTIC AND SHEEPROCK MOUNTAINS ANOMALIES}

Variations of more than 10 mgals occur in the Bouguer anomaly values over the Sheeprock and West Tintic Mountains. Some of the variations have an apparent correlation with surface geology, but others do not. The highest values occur over or near windows in the Sheeprock thrust fault. The upper plate of the thrust is composed largely of clastic rocks which are probably less dense than the underlying predominantly carbonate rocks; therefore, higher gravity values would be expected over windows in the thrust. Low values in the west-central Sheeprock Mountains may reflect the presence of the granite in this area. The cause of the low west of Vernon Creek is not apparent. The lowest values may be effected by a local accumulation of lowdensity valley fill, but the anomaly also extends over Precambrian and Paleozoic rocks. An east-trending fault in the range east of Clyde Ranch may be reflected in the gravity data, but more data are needed to define the gravity variations in this area.

Considerable local gravity relief occurs over the alluvium-covered areas south of the Sheeprock and West Tintic Mountains. The gravity variations in this area probably reflect, in large part, relief on the surface of the pre-Tertiary rocks. Gravity highs occur over Paleozoic outcrops in the hills west of Jericho and east of Rockwell Ranch. A low indicating thicker cover of low density material extends northwest from Rockwell Ranch. The gravity gradient along the northeast side of this low is continuous with a larger gradient east of the ranch and suggests a fault displacing the bedrock surface. Northeast of this postulated fault the bedrock probably rises gradually toward the Sheeprock Mountains. A smaller low indicating a local structural depression occurs about 4 miles northeast of the ranch. A depression of the Paleozoic rock is indicated by the gravity data between the West Tintic Mountains and the hills west of Jericho.

In the West Tintic Mountains magnetic highs occur over the major areas of extrusive and intrusive igneous rock. The positive magnetic zone that extends across the southern parts of the East and West Tintic Mountains and Tintic Valley terminates at the west edge of the exposure of igneous rock near Cherry Creek. The westernmost closed high in this zone is centered near the southeast corner of an exposed dike of rhyolite vitrophyre. This intrusive, which cuts both Precambrian and Tertiary rocks, is 1,500-2,000 feet wide and more than 11,500 feet long, and it dips about $80^{\circ} \mathrm{E}$. It may be a partial cause of the local magnetic high. The magnetic high near the south end of the West Tintic Mountains may reflect the presence of a granite or quartz monzonite stock that is mostly concealed beneath younger lava flows.

An extensive magnetic high occurs over the granite stocks in the west-central Sheeprock Mountains and over outcrops of the monzonite and aplitic granite in the southwest Sheeprock Mountains. This magnetic anomaly indicates a major northwest-trending zone of intrusive rock lying along the southwest flank of the Sheeprock Mountains and extending southeast into the Sevier Desert. The crest of the closed magnetic high southeast of Clyde Ranch is about 2 miles west of the intrusive igneous rocks exposed along the southwest side of the Sheeprock Mountains. Alluvium covers most of the surface near the crest of the magnetic high, but rhyolite vitrophyre crops out 4 miles north of Rockwell Ranch, and Tertiary volcanic rocks crop out in several places. Nine holes have been drilled in the area of the magnetic high by the New Jersey Zinc Co. (R. E. Radabaugh, written commun., 1965). Quartz monzonite was penetrated at depths ranging from 115 to 845 feet in five of the holes between the exposed intrusive rock and the crest of the anomaly. West and south of the holes penetrating quartz monzonite, but also near the crest of the magnetic high, four holes ranging in depth from 910 to 1,060 feet were bottomed in Tertiary sedimentary and volcanic rocks. Although the volcanic rock may contribute to the magnetic high, the magnetic 
data suggest the presence of an intrusive mass underlying an area extending as much as 3 miles west of the outcrops of intrusive rock. The intrusive mass is apparently overlain by several thousand feet of older and younger rocks along its southwest side.

Several small monzonite bodies within the Precambrian and Paleozoic rocks west of Cherry Creek are completely off the magnetic anomaly. This suggests that these monzonite bodies have very low susceptibility, or that they have limited depth extent and may be sill-like apophyses from a parent body to the west.

The magnetic anomalies that are attributed to intrusive rocks in the Sheeprock Mountains are much smaller in amplitude than the major anomaly produced by intrusive rock in the East Tintic Mountains. This amplitude difference probably indicates a lower content of magnetite in the intrusives in the West Tintic area. Six samples of the unaltered intrusive from the Sheeprock Mountains ranged in susceptibility from $0.37 \times 10^{-3}$ to $2.60 \times 10^{-3} \mathrm{cgs}$ units and averaged $1.24 \times 10^{-3} \mathrm{cgs}$ units. Four samples from the East Tintic Mountains ranged from $2.07 \times 10^{-3}$ to $5.40 \times 10^{-3} \mathrm{cgs}$ units and averaged $3.44 \times 10^{-3} \mathrm{cgs}$ units. Although the number of samples is very small, the measured susceptibilities are consistent with the postulated lower magnetite content of the West Tintic intrustive rocks.

A magnetic high in the area of Desert Mountain appears to be related to the granite bodies that crop out there. The magnetic data indicate that the granite extends under the Precambrian sedimentary rock on the west side of Desert Mountain and also under the alluvium to the north. The magnetic low over the Tertiary volcanic rocks east of Desert Mountain suggests that these rock may have inverse remanent magnetization.

\section{INTERPRETATION OF REGIONAL STRUCTURE}

All the major magnetic anomalies appear to be related directly to Tertiary igneous rocks, and no magnetic effect of the Precambrian basement complex is recognized. The igneous rocks and related magnetic anomalies occur in a broad west-trending belt that is similar to belts through the Bingham and Park City areas on the north (Mabey and others, 1964) and through the Milford area on the south (unpub. data). These belts coincide with mineral belts which account for 95 percent of the copper, lead, silver, gold, and zinc produced in Utah (Hilpert and Roberts, 1964). Thus, regional magnetic surveys are a valuable tool in studying the mineral belts, particularly in areas with an extensive cover of Cenozoic sedimentary rocks.

Fuller (1964) considered the east-west interruptions of magnetic anomalies in the Western United States as an expression of deep fracture patterns that are partly decoupled from the upper crust. He cited one example of an east-west offset of a magnetic anomaly in eastern Nevada as indicating the possibility that 30 miles of left-lateral movement had occurred on one of the inferred fractures.

In western Utah the present gross distribution of the west-trending belts of igneous rocks does not appear to be controlled by faulting younger than the igneous rocks. Abundant evidence suggests that the present distribution of the Tertiary igneous rocks is virtually the same as the original distribution. The belts of igneous rocks were probably controlled by deep-seated structures that influenced either the formation or upward movement of the magma. The absence of major surface structures coincident with or parallel to these belts of abundant igneous rocks suggests that the controlling structures are largely decoupled from the upper crust.

The difference in magnetic expression between the intrusive rocks in the Sheeprock and West Tintic Mountains and those in the East Tintic Mountains may be related to a fundamental difference in rock type and method of emplacement. This difference may help explain why economic concentrations of minerals are much more abundant in the East Tintic Mountains.

Although the utility of gravity observations in determining the depth to Precambrian crystalline basement rock in the Basin and Range province has not been proved, the highest Bouguer anomaly values in the vicinity of the Wasatch front occur over the exposed Precambrian complex on Antelope Island (Cook and Berg, 1961). If other factors remain constant, other basement highs should also be reflected as gravity highs. The Sheeprock uplift, which was defined by Eardley (1940, pl. 1, fig. 4) and illustrated as a basement high, occupies the northwestern part of the mapped area. The geophysical data do not support the concept of basement uplift in the Sheeprock Mountain area, but they are consistent with a structural interpretation that assigns the Precambrian sedimentary rocks in this area to the upper plate of a major overthrust that extends over Paleozoic rocks that lie on other thrust sheets.

\section{REFERENCES CITED}

Behrendt, J. C., and Woollard, G. P., 1961, An evaluation of the gravity control network in North America: Geophysies, $\nabla$. 26 , no. 1, p. 57-76.

Cohenour, R. E., 1959, Sheeprock Mountains, Tooele and Juab Counties [Utah]: Utah Geol. and Mineralog. Survey Bull. 63, $201 \mathrm{p}$.

Cook, K. L., and Berg, J. W., Jr., 1961, Regional gravity survey along the central and southern Wasatch front, Utah: U.S. Geol. Survey Prof. Paper 316-E, p. 75-89. 
Crittenden, M. D. Jr., Sharp, B. J., and Calkins, F. C., 1952, Geology of the Wasatch Mountains east of Salt Lake CityParleys Canyon to Traverse Range, in Utah Geol. Soc. Guidebook 8, Central Wasatch Mountains, Utah: p. 1-37.

Duerksen, J. A., 1949, Pendulum gravity data in the United States: U.S. Coast and Geod. Survey Spec. Pub. 244.

Eardley, A. J., 1939, Structure of the Wasatch-Great Basin region: Geol. Soc. America Bull., v. 50, no. 8, p. 1277-1310.

Eardley, A. J., and Hatch, R. A., 1940, Precambrian crystalline rocks of north-central Utah: Jour. Geology, v. 48, no. 1, p. 58-72.

Fuller, M. D., 1964, Expression of $\mathrm{E}-\mathrm{W}$ fractures in magnetic surveys in parts of the U.S.A.: Geophysics, v. 29, no. 4, p. $602-622$.

Groff, S. L., 1959, Geology of the West Tintic Range and vicinity, Tooele and Juab Counties, Utah : Utah Univ. Ph. D. dissert.; also on microfilm from University Microfilms, Inc., Ann Arbor, Mich.

Hilpert, L. S., and Roberts, R. J., 1964, Economic geology, in Mineral and water resources of Utah: Utah Geol. and Mineralog. Survey Bull. 73, p. 28-37.

Kane, M. F., 1962, A comprehensive system of terrain corrections using a digital computer: Geophysics, v. 27 , no. 4 , p. $455-462$.

Mabey, D. R. Crittenden, M. D., Jr., Morris, H. T., Roberts, R. J., and Tooker, E. W., 1964, Aeromagnetic and general- ized geologic map of part of north-central Utah: U.S. Geol. Survey Geophys. Inv. Map GP-422.

Morris, H. T., 1957, General geology of the East Tintic Mountains, Utah, in Utah Geol. Soc. Guidebook 12, East Tintic Mountains and ore deposits of the Tintic mining districts : p. 1-56.

Morris, H. T., and Lovering, T.S., 1961, Stratigraphy of the East Tintic Mountains, Utah: U.S. Geol. Survey Prof. Paper 361, 145 p. [1962].

Schoff, S. L., 1951, Geology of the Cedar Hills, Utah: Geol. Soc. America Bull., v. 62, no. 6, p. 619-645.

Spieker, E. M., 1949, The transition between the Colorado Plateaus and the Great Basin in central Utah, in Utah Geol. Soc. Guidebook 4, Geology of Utah : $106 \mathrm{p}$.

Stokes, W. L., 1963, Geologic map of northwestern Utah: Utah Univ., Coll. Mines and Mineral Industries.

Swick, C. H., 1942, Pendulum gravity measurements and isostatic reductions: U.S. Coast and Geod. Survey Spec. Pub. 232.

Thomas, G. H., 1958, Geology of Indian Springs quadrangle, Tooele and Juab Counties, Utah: Brigham Young Univ. Research Studies, Geology Ser., v. 5, no. 4, 35 p.

Williams, N. C., 1954, Nonpegmatite beryl occurrence, Sheeprock Mountains, Utah [abs.]: Geol. Soc. America Bull., v. 65, no. 12, p. 1388. 